\title{
STUDI PENGGUNAAN VARIABLE SPEED DRIVE UNTUK PENGATURAN KECEPATAN MOTOR EXHAUST FAN PADA DYNO TEST ROOM PT. TRAKINDO UTAMA PEKANBARU
}

\author{
Elham Prasetyo, Elvira Zondra, Usaha Situmeang \\ Program Studi Teknik Elektro, Fakultas Teknik, Universitas Lancang Kuning \\ Jl. Yos Sudarso km. 8 Rumbai, Pekanbaru, Telp. (0761) 52324 \\ Email: elhamprst3@gmail.com, elviraz@unilak.ac.id,usaha@unilak.ac.id
}

\begin{abstract}
ABSTRAK
Exhaust fan adalah peralatan berupa sudu-sudu yang berputar dan memanfaatkan gaya sentrifugal untuk membuang exhaust gas hasil pembakaran bahan bakar solar engine diesel pada saat dilakukan tes pembebanan penuh. Dengan exhaust fan, gas karbondioksida yang dihasilkan oleh engine diesel memungkinkan untuk dibuang dengan cepat sehingga tidak memenuhi ruangan dan membahayakan bagi setiap karyawan. Pengoperasian exhaust fan dilakukan sesuai jadwal pengetesan engine. Exhaust fan tersebut digerakkan oleh motor induksi 3 phasa $30 \mathrm{~kW}$ dengan putaran nominal secara konstan. Pada saat pengetesan engine dengan nilai aliran gas buang yang rendah, exhaust fan tetap dioperasikan dengan kecepatan nominal. Operasional motor exhaust fan dengan kecepatan konstan seperti ini akan mengakibatkan konsumsi daya listrik yang relatif tinggi dari pada motor dengan kecepatan berubah-ubah sesuai kebutuhan. Sebagai pertimbangan hasil perhitungan untuk engine C 18 Caterpillar kapasitas $831 \mathrm{hp}$ yang sebelumya membutuhkan operasional exhaust fan dengan daya $24,7927 \mathrm{~kW}$ nilai sama untuk semua model engine, setelah penggunaan VSD dapat dikurangi sebesar 14,35\% menjadi 21,2343 kW saja. Penelitian ini bertujuan mendapatkan probabilitas hubungan antara konsumsi energi listrik, frekuensi pada variable speed drive, putaran motor induksi dan nilai aliran udara pada cerobong exhaust fan. Nilai aliran udara exhaust fan tersebut akan disesuaikan dengan nilai aliran gas pembakaran yang dihasilkan oleh engine. Analisa optimasi motor exhaust fan ini sedianya akan menggunakan Matematic Analysis dan simulasi menggunakan simulink matlab sehingga diharapkan ada solusi untuk melakukan penghematan terhadap konsumsi daya motor, kemudian bisa diterapkan dalam semua pengoperasian motor yang ada di perusahaan.
\end{abstract}

Kata kunci : variable speed drive, motor induksi, exhaust fan

\begin{abstract}
The exhaust fan is a rotary blade device which produces centrifugal force to remove exhaust gas from diesel fuel combustion during a full load test. With exhaust fans, the carbondioxide gases that generated by the diesel engine allows to be disposed quickly so that it does not fill the room and harm to every employee. The operation of exhaust fan is carried out according to the engine test schedule. The exhaust fan is driven by a 3 phase induction motor of $30 \mathrm{~kW}$ with constant rotation. When testing the engine with a low Exhaust Gas flow value, the exhaust fan remains operated at rated speed. Operational exhaust fan with a constant speed like this will result in relatively high power consumption of the motor with the speed of change as needed. Considering the calculation results for C 18 engine Caterpillar capacity of 831 hp which previously required operational exhaust fan with $24,7927 \mathrm{~kW}$ of equal value for all engine models, after the use of VSD can be reduced by $14.35 \%$ to $21.2343 \mathrm{~kW}$ only. This study aims to obtain the probability of relationship between electrical energy consumption, frequency on the variable speed drive, induction motor rotation and the value of air flow in the exhaust fan chimney. The value of the exhaust fan air flow will be adjusted to the combustion gas flow value generated by the engine. The optimization analysis of this motor exhaust fan will be using Matematic Analysis and simulation using matlab simulink so it is expected there is a solution to make savings to motor power consumption, then it can be applied in all the motor operation in the company.
\end{abstract}

Keywords: variable speed drive, induction motor, exhaust fan

\section{PENDAHULUAN}

Exhaust fan pada dyno test room PT. Trakindo Utama dioperasikan oleh motor induksi 3 phasa $30 \mathrm{~kW}$. Exhaust fan tersebut dioperasikan pada putaran $998 \mathrm{rpm}$ ( rotation per minutes) secara konstan. Putaran operasional exhaust fan akan tetap sama untuk setiap engine diesel yang dilakukan pengetesan. Sedangkan spesifikasi engine diesel 
beraneka ragam. Dari displacement ruang bakar yang relatif kecil sehingga menghasilkan flow rate karbondioksida yang juga relatif sedikit sampai displacement besar dengan hasil karbondioksida yang lebih banyak. Banyaknya jumlah karbondioksida yang dihembuskan ke ruangan akan berbanding lurus dengan besarnya ruang bakar dan juga daya mekanik dari engine diesel itu sendiri. Flow rate karbondioksida yang dihasilkan seharusnya sebanding dengan putaran exhaust fan dengan artian semakin banyak kandungan gas karbondioksida semakin cepat putaran fan untuk membuang gas tersebut keluar ruangan.

Jika memperhatikan aplikasi motor induksi maka motor sering dioperasikan menggunakan sistem konvensional dengan putaran konstan sehingga hasil dari konsumsi energi yang digunakan juga bernilai maksimum. Lain halnya apabila putaran motor dapat diatur sesuai dengan kebutuhan maka daya listrik yang terpakai relatif kecil daripada motor selalu berputar dengan putaran nominal. Upaya untuk pengaturan putaran motor ini dapat menggunakan peralatan tambahan yang disebut dengan Variable Speed Drive ( VSD ). Inisiatif penggunaan VSD ini berawal dari diskusi-diskusi dengan para superior pada PT. Trakindo Utama untuk mengoptimalkan pengoperasian semua sistem pada dyno test room sehingga pada akhirnya dicapai nilai keuntungan optimal dari proses dyno test engine diesel itu sendiri. Hal ini sejalan dengan perusahaan yang mengharapkan setiap karyawan mempunyai inovasi-inovasi untuk memperlancar proses pekerjaan. Seperti apa kontruksi dari VSD yang sesuai untuk digunakan pada dyno test room ini maka dalam penelitian ini akan dianalisa parameterparameter yang perlu seperti ukuran ruangan, nilai karbondioksida yang dihasilkan setiap engine diesel, spesifikasi motor dan exhaust fan kemudian konstruksi dari saluran ataupun ventilasi.

Tujuan utama penggunaan Exhaust fan adalah untuk membuang exhaust gas dan juga panas hasil pembakaran bahan bakar solar engine diesel pada saat dilakukan tes pembebanan penuh. Dengan exhaust fan, gas karbondioksida yang dihasilkan oleh engine diesel memungkinkan untuk dibuang dengan cepat sehingga tidak memenuhi ruangan dan membahayakan bagi setiap karyawan. Putaran operasional dari exhaust fan ini akan disesuaikan dengan nilai flow rate gas buang di area cerobong hisapan dan nilai beban perpindahan panas setiap engine. Dengan dua nilai parameter ini maka diharapkan di dalam ruangan dyno test terjaga nilai kandungan karbondioksida berserta panas udara tidak melebihi nilai standar keselamatan dan performa engine diesel yang telah ditetapkan.

\section{METODE PENELITIAN}

\subsection{Sistem Exhaust fan Pada Dyno Test Room PT. Trakindo Utama.}

Dyno Test Room adalah suatu ruangan berukuran $6 m \times 6 m \times 6 m\left(216 \mathrm{~m}^{3}\right)$ yang digunakan untuk proses finishing engine diesel setelah dilakukan perbaikan. Yaitu dilakukan performance test dengan beban penuh sehingga didapatkan parameter-parameter yang kemudian disesuaikan dengan spesifikasi pabrik. Setiap engine diesel yang dites memiliki spesifikasi flow rate ( aliran ) gas buang yang berbeda-beda sesuai dengan tenaga yang dihasilkan.

Exhaust fan pada dyno test room merupakan peralatan vital yang harus ada untuk membuang gas karbondioksida hasil pembakaran bahan bakar solar engine diesel. Dengan exhaust fan melalui cerobong luar berukuran $0,89 m \times 1,7 m$, gas karbondioksida yang dihasilkan oleh engine diesel memungkinkan untuk dibuang dengan cepat sehingga tidak memenuhi ruangan dan membahayakan bagi setiap karyawan. Pengoperasian exhaust fan relatif dilakukan sesuai jadwal pengetesan engine. Kontruksi exhaust fan ditunjukkan seperti pada Gambar 2.1 dan 2.2.

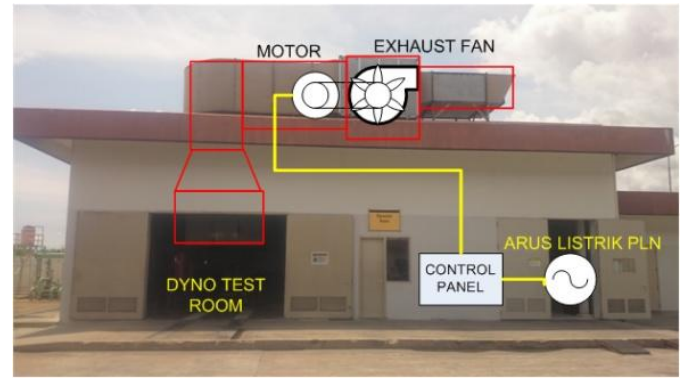

Gambar 2.1 exhaust fan tampak dari luar ruangan.

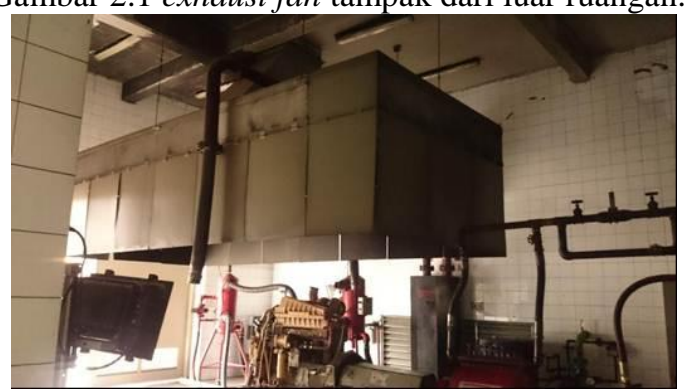

Gambar 2.2 exhaust fan tampak dari dalam ruangan.

Exhaust fan tersebut digerakkan oleh motor induksi 3 phasa $30 \mathrm{~kW}$ dengan putaran nominal secara konstan. Untuk menyalurkan putaran motor induksi ke exhaust fan pada poros rotor motor induksi dipasang sebuah pulley dengan belting yang terhubung ke pulley satunya yang dipasang pada poros sudu-sudu exhaust fan seperti Gambar 2.3. 


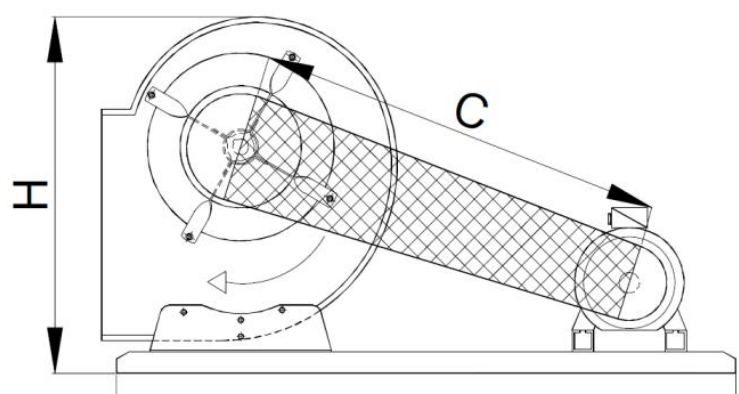

Gambar 2.3 belting sebagai penyalur putaran Motor induksi ke exhaust fan.

Motor induksi tiga phasa merk kruger $30 \mathrm{~kW}$ tersebut dikontrol menggunakan Schneider electric altistart 48 sebagai softstart seperti pada Gambar 2.3. Sistem kontrol menggunakan altistart 48 ini pada dasarnya mirip dengan penggunaan sistem DOL konvensional dengan memanfaatkan perubahan rangkaian stator hubungan star delta sekaligus dengan Altistart 48 motor dapat distel waktu akselerasi sampai putaran nominal sehingga arus start yang tinggi secara tiba-tiba dapat dikurangi.

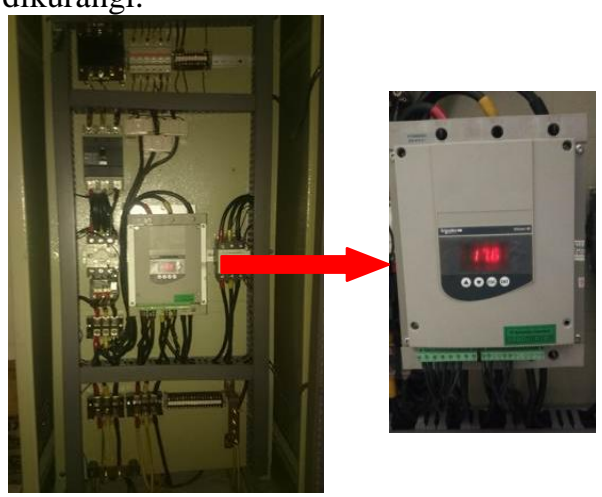

Gambar 2.4 sistem pengendali menggunakan Altistart 46.

Sedangkan gambaran dari rangkaian VSD seperti Gambar 2.5 merk Fuji Electric Frenic-Eco.

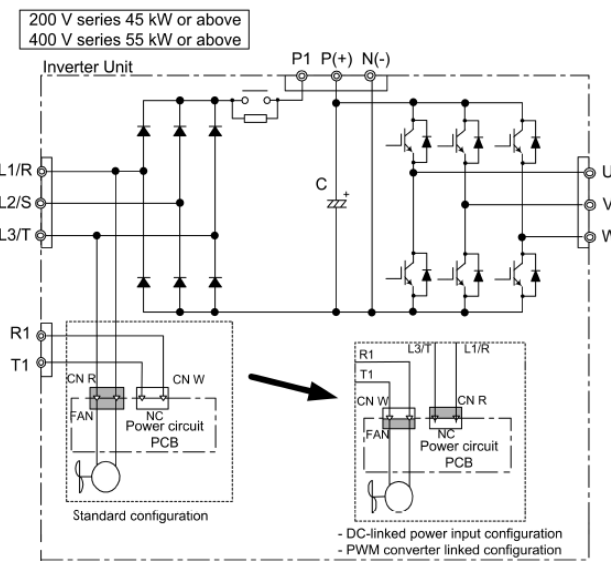

Sumber : Manual book Fuji Electric FrenicEco.

Gambar 2.5 VSD merk Fuji Electric Frenic-Eco.

\subsection{Data Spesifikasi Exhaust fan.}

Data exhaust fan merk kruger diambil dari name plate yang terpasang pada fan tersebut seperti pada Tabel 2.1.

Tabel 2.1 Spesifikasi Teknik Exhaust fan

\begin{tabular}{||l|c||}
\hline \multicolumn{1}{|c|}{ Parameter } & Spesifikasi \\
\hline Merk & KRUGER \\
\hline Type & $\begin{array}{c}\text { CFT 900-D(BDB 900/XM } \\
\text { CLII) CCW }\end{array}$ \\
\hline Code & GGK0019D-30-GO \\
\hline Serial & $1103046 \mathrm{Y}-\mathrm{A} 0060904111 \mathrm{PTK}$ \\
\hline Fan $\mathrm{cmh}$ & 68000 \\
\hline Fan Speed & $973 \mathrm{rpm}$ \\
\hline Pressure & $635 \mathrm{~Pa}$ \\
\hline
\end{tabular}

Sumber : Brosur spesifikasi Kruger BDB double inlet centrifugal fan.

\subsection{Data Spesifikasi Motor Induksi.}

Data motor induksi merk kruger diambil dari name plate yang terpasang pada motor tersebut seperti pada Tabel 2.2.

Tabel 2.2 Spesifikasi Teknik Motor Induksi

\begin{tabular}{|l|c||}
\hline \multicolumn{1}{|c|}{ Parameter } & Spesifikasi \\
\hline Merk & KRUGER \\
\hline Type & B060030FMB3-U \\
\hline Tegangan & $440-480 \mathrm{~V}$ \\
\hline Arus & $40-44.3 \mathrm{~A}$ \\
\hline Power factor & 0,8 \\
\hline Power & $30 \mathrm{~kW}$ \\
\hline Rpm & $980 \mathrm{Rpm}$ \\
\hline Pole & 6 \\
\hline Frequensi & $50 \mathrm{~Hz}$ \\
\hline Connection & Delta \\
\hline
\end{tabular}

Sumber : Name plate spesifikasi Kruger induction motor.

\subsection{Data Spesifikasi Flow Rate Exhaust Gas.}

Nilai Exhaust flow rate dari setiap engine diesel diambil dari data spesifikasi pabrik yang ada pada setiap model engine Caterpillar tersebut seperti pada Tabel 2.3. Sebagai contoh untuk engine model 3306 dengan displacement setiap ruang bakar mendekati 3 liter dengan 6 buah silinder atau ruang bakar, membutuhkan suplai udara bersih sebesar 695 cfm dalam proses pembakaran sehingga menhasilkan tenaga mekanikal $349 \mathrm{hp}$ dan exhaust gas $2.055 \mathrm{cfm}$ dengan temperature gas $1.031{ }^{\circ} \mathrm{F}$ dan mempunyai exhaust heat rejection atau nilai perpindahan panas sebesar 14.956 btu/minutes selengkapnya untuk engine model lainnya seperti Tabel 2.3 di bawah.

Tabel 2.3 Data Exhaust Gas flow rate engine diesel

\begin{tabular}{|c|c|c|c|c|c|c|}
\hline \multirow[b]{2}{*}{ No } & \multirow[b]{2}{*}{$\begin{array}{l}\text { Model } \\
\text { Engine }\end{array}$} & \multirow{2}{*}{$\begin{array}{l}\text { Daya } \\
\text { hp }\end{array}$} & \multirow[b]{2}{*}{$\begin{array}{l}\text { Air butaks } \\
\text { Flow, sfm }\end{array}$} & \multirow{2}{*}{$\begin{array}{l}\text { Exhoust Heat } \\
\text { Rejection } \\
\text { btu/min }\end{array}$} & \multicolumn{2}{|c|}{ Exhanst Gas } \\
\hline & & & & & $\begin{array}{c}\text { Temperature } \\
\left({ }^{\circ} \mathrm{F}\right)\end{array}$ & $\begin{array}{l}\text { Flons } \\
(\mathrm{cfm})\end{array}$ \\
\hline 1 & C 18 & 831 & 1.465 & 31.847 & 1.035 & 4.308 \\
\hline 2 & 3408 & 603 & 1.292 & 26.956 & 1.006 & 3.686 \\
\hline 3 & 3406 & 590 & 1.133 & 20.302 & 907 & 3.015 \\
\hline 4 & 3306 & 349 & 695 & 14.956 & 1.031 & 2.055 \\
\hline
\end{tabular}

Sumber : Caterpillar service manual. 


\subsection{Langkah-langkah Penelitian.}

Tahapan-tahapan seperti flow chart Gambar 2.7 yang akan di lakukan dalam pelaksanaan penelitian tugas akhir ini agar hasil yang dicapai tidak menyimpang dari tujuan yang telah ditentukan yaitu antara lain :

1. Melakukan pengambilan data kecepatan motor induksi, nilai arus listrik, tegangan listrik, nilai power faktor atau $\cos \varphi$, data spesifikasi motor induksi dan exhaust fan, ukuran diameter pulley, nilai kecepatan udara yang dihasilkan exhaust fan serta kecepatan udara pada lubang-lubang ventilasi, ukuran ventilasi, ruangan dan data flow rate gas buang setiap engine Caterpillar.

2. Melakukan perhitungan aliran udara pada cerobong fan dari data kecepatan sudu-sudu fan dan spesifikasi fan serta menghitung konsumsi daya listrik motor induksi dan kecepatan poros pada motor induksi dari data kelistrikan dan data motor induksi.

3. Melakukan perhitungan dengan variable yang berbeda mengacu pada beberapa nilai Exhaust Gas flow rate engine diesel sehingga didapatkan probabilitas hubungan antara nilai frekuensi variable speed drive, daya masukan motor induksi, kecepatan motor, kecepatan exhaust fan dan aliran udara yang dihasilkan.

4. Melakukan simulasi menggunakan aplikasi atau program komputer dalam hal ini simulasi menggunakan software simulink matlab seperti Gambar 2.6 dan validasi perhitungan menggunakan script code matlab.

5. Semua hasil perhitungan dikomparasikan dengan hasil validasi menggunakan script code matlab dan simulasi menggunakan simulink.

6. Meninjau kembali menggunakan rujukan yang tepat jika terjadi perbedaan nilai hasil perhitungan dan validasi ataupun simulasi.

7. Memberikan kesimpulan dari semua hasil yang didapat.

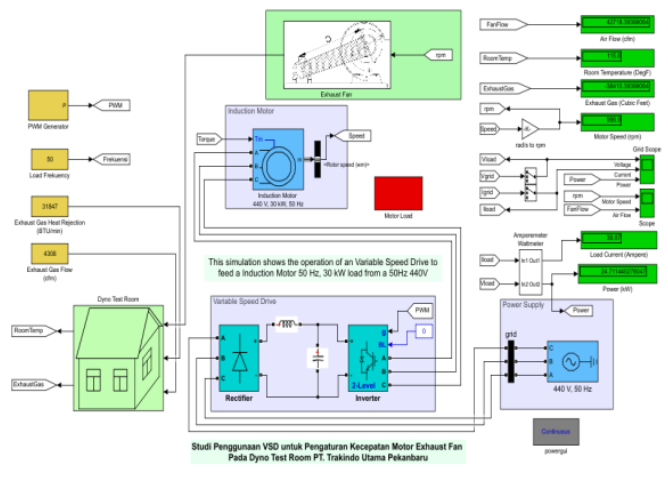

Gambar 2.6 Blok simulasi Simulink matlab

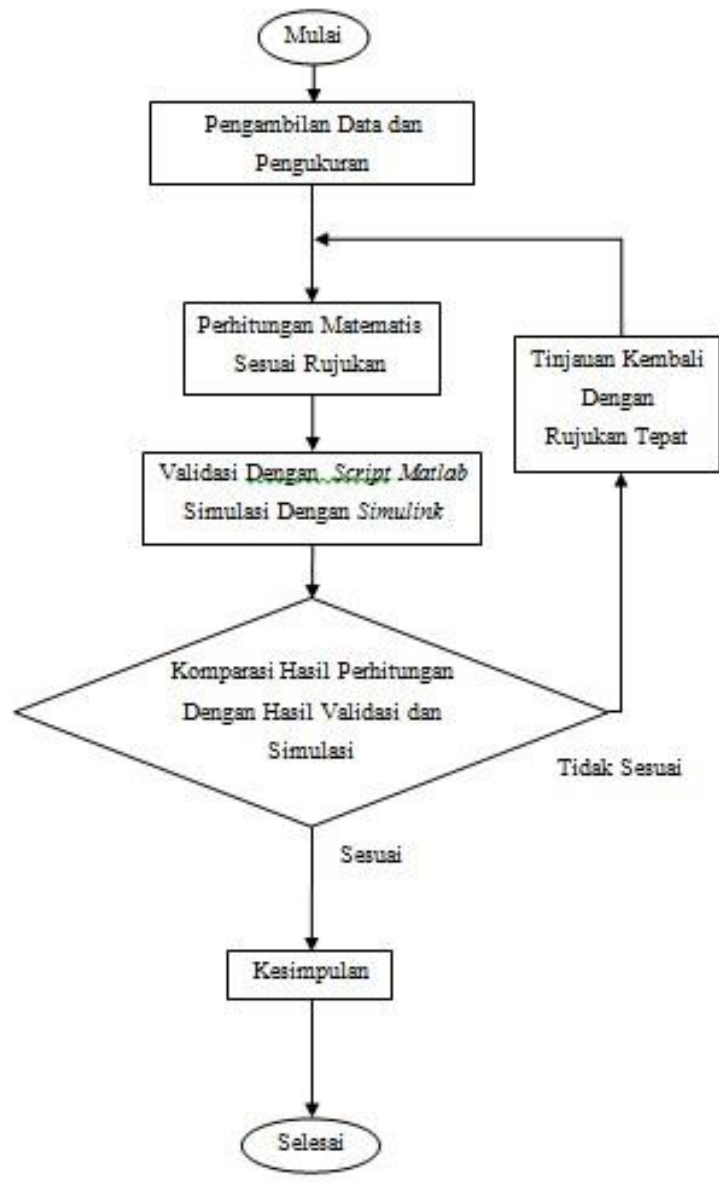

Gambar 2.7 Flow Chart Penelitian.

\section{PEMBAHASAN}

\subsection{Data Pengukuran dan Nilai Flow Rate Engine Diesel.}

Berdasarkan metode pengukuran data yang dilakukan maka diperoleh data yang akan digunakan untuk analisis kinerja motor induksi, seperti Tabel 3.1 .

Tabel 3.1 Data Pengukuran Parameter Motor Induksi Exhaust fan

\begin{tabular}{||c|c|c|c|c|c|c||}
\hline Kondisi Beban & $\begin{array}{c}\text { Arus } \\
\text { Stator } \\
(\mathrm{A})\end{array}$ & $\begin{array}{c}\text { Tegangan } \\
\text { Stator } \\
(\mathrm{V})\end{array}$ & $\begin{array}{c}\text { Freluenai } \\
(\mathrm{Hz})\end{array}$ & $\begin{array}{c}\text { Kecepatan } \\
\text { Rotor } \\
(\mathrm{mgm})\end{array}$ & $\begin{array}{c}\text { Temperatur } \\
\text { udara luar } \\
(\mathrm{F})\end{array}$ & $\begin{array}{c}\text { Kecapstan } \\
\text { Udara } \\
(\mathrm{m} / \mathrm{s})\end{array}$ \\
\hline Dengan Beban & 40 & 440 & 50 & 998 & 86 & 13,3 \\
\hline Tanpa Beban & 20 & 435 & 50 & 996 & 86 & 0 \\
\hline
\end{tabular}

\subsection{Pengoperasian Exhaust fan Sebelum Penggunaan VSD}

Berdasarkan data yang diperoleh dari name plate motor induksi serta ukuran pada Tabel 3.1 maka dapat dihitung parameter-parameter sebagai berikut :

3.2.1 Kecepatan Motor Pada Frekuensi $50 \mathrm{~Hz}$.

1. Kecepatan sinkron motor dapat dihitung sebagai berikut : 


$$
\begin{aligned}
& n_{\text {sync }}=\frac{120 \times f_{\text {se }}}{p} \\
& n_{\text {sync }}=\frac{120 \times 50}{6} \\
& n_{\text {sync }}=\frac{6.000}{6} \\
& n_{\text {sync }}=1.000 \mathrm{rpm}
\end{aligned}
$$

2. Nilai slip motor dapat dihitung sebagai berikut :

$$
\begin{aligned}
& s=\frac{\left(n_{\text {sync }}-n_{m}\right)}{n_{\text {sync }}} \times 100 \% \\
& n_{\text {sync }}=\frac{(1.000-998)}{1.000} \times 100 \% \\
& s=\frac{2}{1.000} \times 100 \% \\
& s=0,002 \times 100 \% \\
& s=0,2 \%
\end{aligned}
$$

3.2.2 Nilai Aliran Udara Yang Dihasilkan Exhaust fan.

Berdasarkan data yang diperoleh, telah diketahui kecepatan udara ( air velocity) seperti Tabel 4.1, nilai kecepatan exhaust fan dan ukuran cerobong keluaran dari exhaust fan. Maka nilai aliran udara dapat dihitung sebagai berikut :

Dari data : $v=13,3 \mathrm{~m} / \mathrm{s}$

$$
A=0,89 m \times 1,7 m
$$

Maka $Q$,

$$
\begin{aligned}
& Q=v \times A \\
& Q=13,3 \times(0,89 \times 1,7) \\
& Q=13,3 \times(1,513) \\
& Q=20,1229 \mathrm{~meter}^{3} / \mathrm{second}^{3} / \mathrm{minutes} \\
& Q=1.207,374 \mathrm{~meter}^{3} / \text { minutes }(\mathrm{cfm}) \\
& Q=42.638,0506 \mathrm{feet}^{3} / \text { }
\end{aligned}
$$

Hasil aliran udara $Q$ diatas selanjutnya kita sebut sebagai $Q_{1}$.

\subsubsection{Nilai Konsumsi Energi Listrik Pada} Frekuensi $50 \mathrm{~Hz}$.

Berdasarkan data yang diperoleh dari name plate motor induksi serta ukuran pada Tabel 3.1 maka dapat dihitung rugi daya motor sebagai berikut

$$
\begin{aligned}
P & =\sqrt{3} \times V \times I \times \cos \varphi \\
\cos \varphi & =\frac{P}{\sqrt{3} \times V \times I} \\
\cos \varphi & =\frac{30.000}{\sqrt{3} \times 440 \times 48,4} \\
\cos \varphi & =\frac{30.000}{36.885,754} \\
\cos \varphi & =0,8133
\end{aligned}
$$

Dari perhitungan di atas diketahui rugi daya motor (Cos $\varphi$ ), nilai tegangan (V) dan arus (I). Maka konsumsi daya motor induksi pada frekuensi $50 \mathrm{~Hz}$ dapat dihitung sebagai berikut :

Dari data: $\mathrm{I}=40 \mathrm{~A}$

$$
\begin{aligned}
\mathrm{V} & =440 \mathrm{~V} \\
\cos \varphi & =0,8133
\end{aligned}
$$

Maka P,

$$
\begin{array}{ll}
P & =\sqrt{3} \times V \times I \times \cos \varphi \\
P & =\sqrt{3} \times 440 \times 40 \times 0.8133 \\
P & =30.484,09421 \times 0,8133 \\
P & =24.792,7138 \text { Watt } \\
P & =24,7927 \mathrm{~kW}
\end{array}
$$

Hasil daya listrik motor induksi $P$ diatas selanjutnya kita sebut sebagai $P_{1}$.

\subsection{Pengoperasian Exhaust fan Saat}

\section{Penggunaan VSD}

Untuk perhitungan semua parameter saat penggunaan VSD, variable frekuensi yang berbeda dihasilkan VSD sebagai acuan awal untuk mendapatkan nilai kecepatan, aliran udara exhaust fan dan nilai konsumsi daya listrik. Maka berdasarkan rujukan-rujukan yang sudah didapatkan maka perhitungan -perhitungan dilakukan seperti di bawah.

3.2.1 Kecepatan Motor Pada Frekuensi $45 \mathrm{~Hz}$.

Jika frekuensi pada VSD ( Variable Speed Drive ) diatur sebesar $45 \mathrm{~Hz}$ maka kecepatan motor dapat dihitung sebagai berikut :

1. Kecepatan sinkron stator

$$
\begin{aligned}
& n_{\text {sync }}=\frac{120 \times f_{\text {se }}}{p} \\
& n_{\text {sync }}=\frac{120 \times 45}{6} \\
& n_{\text {sync }}=900 \mathrm{rpm}
\end{aligned}
$$

2. Kecepatan mekanikal poros rotor dapat dihitung sebagai berikut :

$$
\begin{aligned}
& s=\frac{\left(n_{\text {sync }}-n_{m}\right)}{n_{\text {sync }}} \\
& n_{m}=n_{s y n}-\left(s \times n_{s y n}\right) \\
& n_{m}=900-(0,002 \times 900) \\
& n_{m}=900-1,8 \\
& n_{m}=898,2 \mathrm{rpm}
\end{aligned}
$$

Dari perhitungan tersebut diketahui bahwa jika VSD diatur pada frekuensi $45 \mathrm{~Hz}$ maka kecepatan mekanikal pada poros rotor $\left(n_{m}\right)$ adalah $898.2 \mathrm{rpm}$. Secara keseluruhan dari perhitungan didapatkan hubungan antara frekuensi pada VSD yang disupai ke stator $\left(f_{s e}\right)$ dan slip motor $(s)$ 
dengan kecepatan mekanikal pada poros rotor $\left(n_{m}\right)$ seperti pada Tabel 3.2.

Tabel 3.2 Hubungan frekuensi dengan kecepatan mekanikal rotor.

\begin{tabular}{|c|c|c|c|}
\hline No & $\begin{array}{c}\text { Freluensi VSD / Stator } f_{s} \\
(\mathrm{~Hz})\end{array}$ & $\operatorname{Slip}(5)$ & $\begin{array}{c}\text { Kecepatan Melkanikal Rotor n, } \\
\text { (mm) }\end{array}$ \\
\hline 1 & 45 & \multirow{8}{*}{0,002} & 898,2 \\
\hline 2 & 40 & & 798,4 \\
\hline 3 & 35 & & 698,6 \\
\hline 4 & 30 & & 598,8 \\
\hline 5 & 25 & & 499,0 \\
\hline 6 & 20 & & 399,2 \\
\hline 7 & 15 & & 299,4 \\
\hline 8 & 10 & & 199.6 \\
\hline
\end{tabular}

Hasil perhitungan dari Tabel 3.2 ditunjukan seperti pada grafik Gambar 3.1 jika frekuensi VSD yang disuplai ke stator bertambah besar maka akan berbanding lurus dengan kecepatan mekanikal rotor sehingga kecepatan bertambah tinggi.

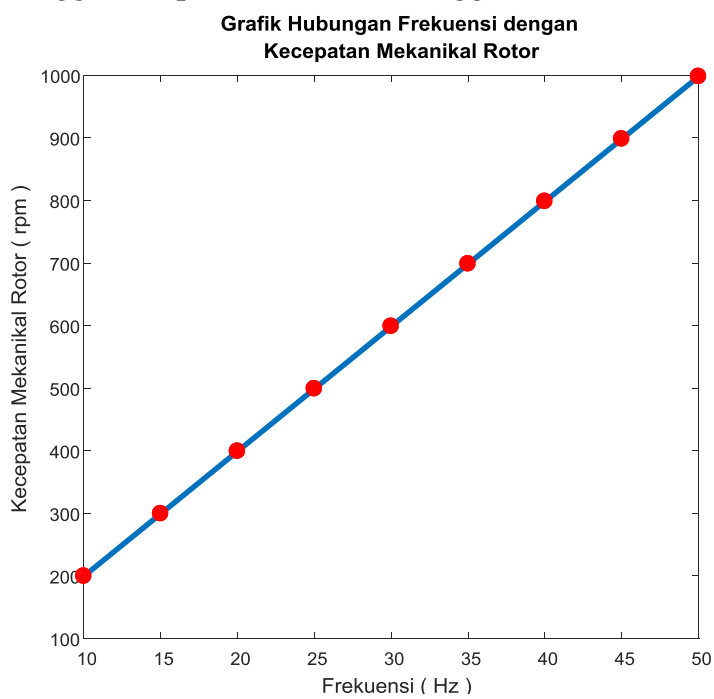

Gambar 3.1 Hubungan antara Frekuensi dan Kecepatan Mekanikal Rotor

Gambar 3.1 menunjukkan hubungan antara frekuensi dan kecepatan mekanikal rotor, dimana perubahan frekuensi sebesar $11 \%$ akan mengakibatkan meningkatnya kecepatan mekanikal rotor senilai $11 \%$.

\subsubsection{Perhitungan Nilai Aliran Udara Yang}

Dihasilkan Exhaust fan.

Dengan hukum fan maka nilai aliran udara dengan variabel kecepatan fan dapat dicari sebagai berikut :

$$
\begin{aligned}
& \frac{Q_{1}}{Q_{2}}=\frac{n_{m 1}}{n_{m 2}} \\
& Q_{2}=\frac{n_{m 2}}{n_{m 1}} \times Q_{1} \\
& Q_{2}=\frac{898,2}{998} \times 42.638,0506 \\
& Q_{2}=0,9 \times 42.638,0506 \\
& Q_{2}=38.374,24554 \mathrm{cfm}
\end{aligned}
$$

Secara keseluruhan dari perhitungan seperti pada Tabel 3.3.

Tabel 3.3 Hasil perhitungan aliran udara

\begin{tabular}{||c|c|c||}
\hline \hline No & Kecapatan Fan (pm) & Aliran Udara (क्m) \\
\hline 1 & 898,2 & $38.374,24554$ \\
\hline 2 & 798,4 & $34.110,44048$ \\
\hline 3 & 698,6 & $29.846,63542$ \\
\hline 4 & 598,8 & $25.582,83036$ \\
\hline 5 & 499,0 & $21.319,02530$ \\
\hline 6 & 399,2 & $17.055,22024$ \\
\hline 7 & 299,4 & $12.791,41518$ \\
\hline 8 & 199,6 & $8.527,61012$ \\
\hline
\end{tabular}

Hasil dari perhitungan dari Tabel 3.3, seperti pada grafik Gambar 3.2.

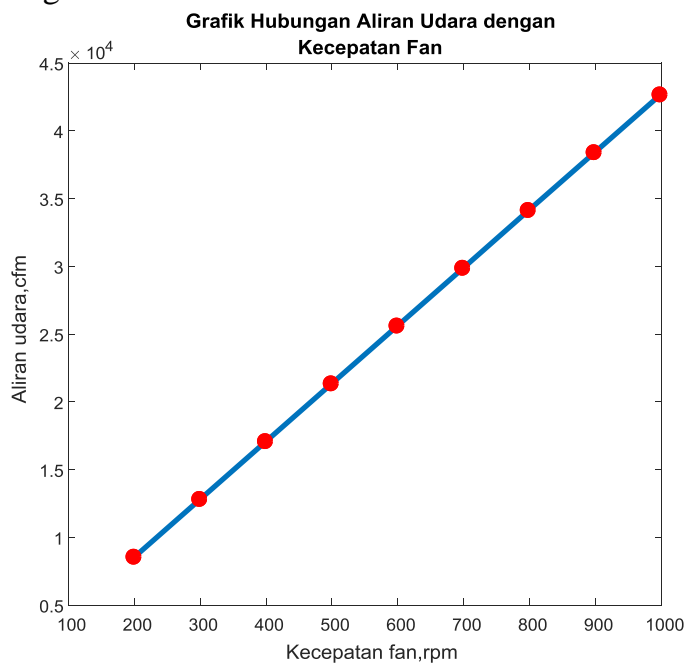

Gambar 3.2 Hubungan antara kecepatan fan dan aliran udara.

Gambar 3.2 menunjukkan hubungan antara kecepatan mekanikal rotor dan aliran udara yang dihasilkan fan, dimana perubahan kecepatan mekanikal rotor sebesar $11 \%$ akan mengakibatkan meningkatnya aliran udara senilai $11 \%$.

3.2.3 Perhitungan Konsumsi Daya Listrik.

Dengan hukum fan nilai konsumsi daya motor dapat dicari sebagai berikut :

$$
\begin{aligned}
& \frac{P_{1}}{P_{2}}=\left(\frac{n_{m 1}}{n_{m 2}}\right)^{3} \\
& P_{2}=\left(\frac{n_{m 2}}{n_{m 1}}\right)^{3} \times P_{1} \\
& P_{2}=\left(\frac{898,2}{998}\right)^{3} \times 24,792 \\
& P_{2}=0,729 \times 24,792 \mathrm{~kW} \\
& P_{2}=18,0734 \mathrm{~kW}
\end{aligned}
$$

Berdasarkan perhitungan diatas dapat dibuat tabel berdasarkan beberapa kondisi seperti Tabel 3.4 . 
Tabel 3.4 Perhitungan konsumsi daya motor

\begin{tabular}{||c|c|c|}
\hline No & Kecepatan motor $($ fan $(\mathrm{mmm})$ & Daya motor $(\mathrm{kW})$ \\
\hline 1 & 898,2 & 18,0739 \\
\hline 2 & 798,4 & 12,6939 \\
\hline 3 & 698,6 & 8,50389 \\
\hline 4 & 598,8 & 5,35522 \\
\hline 5 & 499,0 & 3,09909 \\
\hline 6 & 399,2 & 1,58673 \\
\hline 7 & 299,4 & 0,66940 \\
\hline 8 & 199,6 & 0.19834 \\
\hline
\end{tabular}

Hasil dari perhitungan dari Tabel 3.4, seperti pada grafik Gambar 3.3.

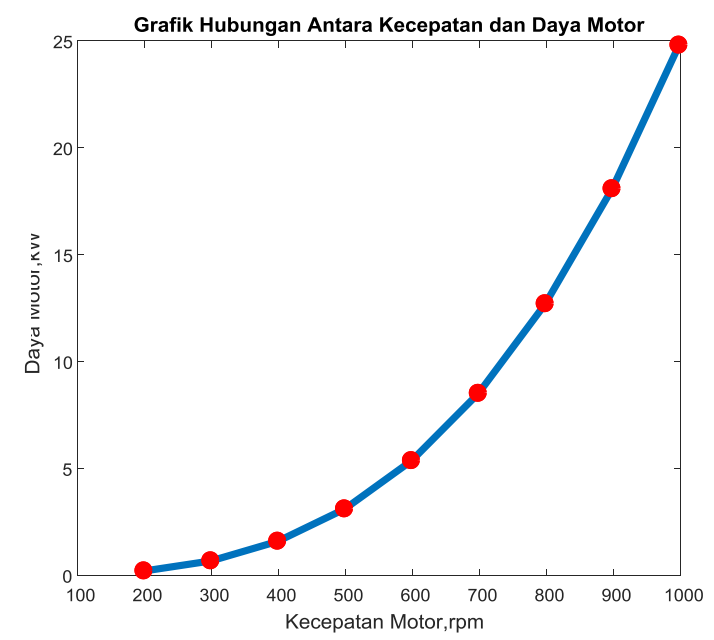

Gambar 3.3 Hubungan antara kecepatan dan daya motor.

Gambar 3.3 menunjukkan hubungan antara kebutuhan daya listrik dengan kecepatan motor. Perubahan kecepatan $11 \%$ akan meningkatkan atau menurunkan kebutuhan daya listrik $23 \%$.

\subsection{Penentuan Setelan Kecepatan Fan Sesuai} Exhaust Gas Flow Rate.

Untuk menentukan kecepatan fan yang disesuaikan dengan exhaust gas flow rate yang dihasikan setiap engine diesel maka pertama-tama harus diketahui nilai volume flow ( aliran volume ) udara yang harus disuplai oleh fan menggunakan data nilai exhaust gas flow rate, nilai suhu udara luar dan dalam ruangan. Aliran volume udara ini dapat dihitung sebagai berikut :

$$
\begin{aligned}
Q_{s} & =\frac{Q_{r s}}{\rho_{s} \times C_{p} \times\left(t_{r}-t_{s}\right)}+\text { Combustion } \cdot \text { Air } \\
Q_{s} & =\left(\frac{31.847}{0,0735 \times 0,24 \times(120-68)}\right)+1.465+4.308 \\
Q_{s} & =\left(\frac{31.847}{0,91728}\right)+5.773 \\
Q_{s} & =(34.718,95168)+5.773 \\
Q_{s} & =40.491,95168 \mathrm{cfm}
\end{aligned}
$$

Untuk menentukan nilai kecepatan mekanikal rotor dapat dihitung sebagai berikut :

$$
\frac{Q_{1}}{Q_{2}}=\frac{n_{m 1}}{n_{m 2}}
$$

$$
\begin{aligned}
& n_{m 2}=n_{m 1} \times \frac{Q_{2}}{Q_{1}} \\
& n_{m 2}=998 \times \frac{40.491,95168}{42.638,05060} \\
& n_{m 2}=998 \times 0,94967 \\
& n_{m 2}=947,7677 \mathrm{rpm}
\end{aligned}
$$

Pada Tabel 4.2 hasil perhitungan kecepatan mekanikal rotor dari data frekuensi dan dipertegas dengan Gambar 4.1 didapatkan kesimpulan bahwa perubahan nilai frekuensi sebanding dengan output nilai kecepatan mekanikal rotor. Maka untuk menentukan nilai frekuensi yang harus diatur pada VSD, dapat dihitung sebagai berikut :

$$
\begin{aligned}
& \frac{f_{1}}{f_{2}}=\frac{n_{m 1}}{n_{m 2}} \\
& f_{2}=f_{1} \times \frac{n_{m 2}}{n_{m 1}} \\
& f_{2}=50 \times \frac{947,7677}{998} \\
& f_{2}=50 \times 0,94967 \\
& f_{2}=47,4834 \mathrm{H}_{\mathrm{z}}
\end{aligned}
$$

\begin{tabular}{|c|c|c|c|c|c|c|}
\hline No & $\begin{array}{l}\text { Model } \\
\text { Engine }\end{array}$ & $\begin{array}{l}\text { Exhoust } \\
\text { Flow } \\
\text { (cfm) }\end{array}$ & $\begin{array}{c}\text { Aliran Udara } \\
\text { Fan } \\
(\mathrm{c} f \mathrm{~m})\end{array}$ & $\begin{array}{c}\text { Kecepatan } \\
\text { Motor } \\
\text { ( mpm) }\end{array}$ & $\begin{array}{l}\text { Frekuensi } \\
(\mathrm{Hz})\end{array}$ & $\begin{array}{c}\text { Daya } \\
\text { Listrik } \\
\text { (kW) }\end{array}$ \\
\hline 1 & & 4.308 & $40.491,95168$ & 947,7677 & 34 & 21,2343 \\
\hline 2 & & 3.686 & $34.364,8829$ & 804 & 40, & 12,9801 \\
\hline 3 & & 3.015 & $26.183,8275$ & 612 & 8 & 5,7416 \\
\hline 4 & 306 & 2.055 & 19.054 .7270 & 446,0011 & 22,3447 & 2,2128 \\
\hline
\end{tabular}

Dengan penyetelan tersebut konsumsi daya listrik yang dibutuhkan oleh motor dapat dihitung sebagai berikut :

$$
\begin{aligned}
& \frac{P_{1}}{P_{2}}=\left(\frac{n_{m 1}}{n_{m 2}}\right)^{3} \\
& P_{2}=P_{1} \times\left(\frac{n_{m 2}}{n_{m 1}}\right)^{3} \\
& P_{2}=24,7927 \times\left(\frac{947,7677}{998}\right)^{3} \\
& P_{2}=24,7927 \times(0,94967)^{3} \\
& P_{2}=24,7927 \times 0,8565 \\
& P_{2}=21,23429 \mathrm{~kW}
\end{aligned}
$$

Secara keseluruhan berdasarkan model atau jenis engine merk Caterpillar yang sering masuk Dyno Test Room maka hasil perhitungan nilai frekuensi VSD dan kecepatan Exhaust fan seperti pada Tabel 3.5.

Tabel 3.5 Tabel Perhitungan nilai frekuensi VSD dan kecepatan Exhaust fan

Hasil perhitungan dari Tabel 3.5 ditunjukan seperti pada grafik Gambar 3.4 jika frekuensi VSD yang disuplai ke stator bertambah besar maka kecepatan mekanikal rotor juga bertambah, aliran udara ( air flow rate) yang dihasilkan fan juga 
bertambah. Begitupun konsumsi daya listrik yang disuplai ke motor juga ikut naik.

Grafik Pengaruh Frekuensi VSD Terhadap Kecepatan Mekanikal Rotor

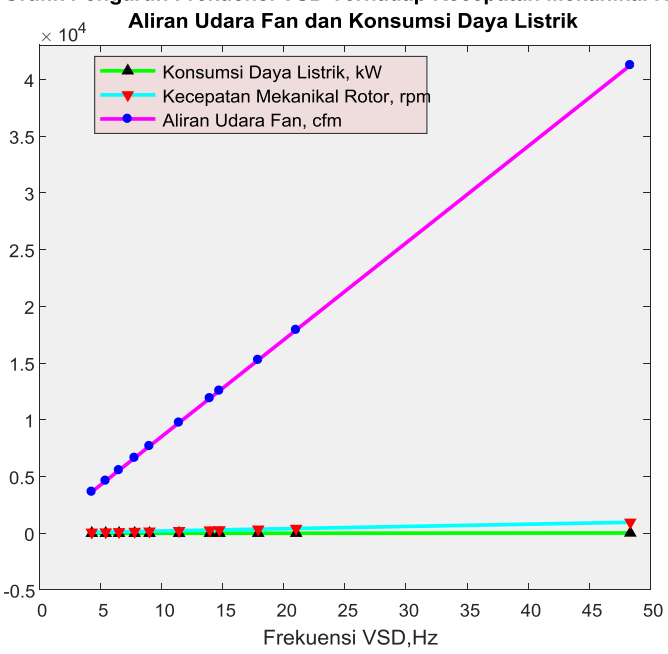

Gambar 3.4 Grafik hubungan frekuensi dengan kecepatan, aliran udara dan daya listrik.

Dari semua perhitungan yang ada, membuktikan bahwa penggunaan VSD berpengaruh terhadap konsumsi daya listrik yang cukup signifikan. Seperti Tabel 3.5 dan 3.6 serta Gambar 3.4 ditunjukkan bahwa selama ini proses pengetesan engine Cat 3306 dengan putaran exhaust fan konstan sebelum penggunaan VSD memerlukan daya $24 \mathrm{~kW}$ dan dari hasil perhitungan setelah penggunaan VSD jika disesuaikan dengan nilai air flow rate Exhaust Gas engine 3306 tersebut, hanya memerlukan daya listrik 2,2128 kW saja.

Tabel 3.6 Perbandingan sebelum dan sesudah penggunaan VSD

\begin{tabular}{|c|c|c|c|c|c|}
\hline \multirow[b]{2}{*}{ No } & \multirow{2}{*}{$\begin{array}{l}\text { Model } \\
\text { Engine }\end{array}$} & \multicolumn{2}{|c|}{ Sebelum Penggunsen VSD } & \multicolumn{2}{|c|}{ Setelah Penggunsen VSD } \\
\hline & & $\begin{array}{c}\text { Freluensi } \\
\text { ( } \mathrm{Hz} \text { ) }\end{array}$ & $\begin{array}{c}\text { Daya Listrik } \\
\text { (kW) }\end{array}$ & $\begin{array}{c}\text { Freluensi } \\
\text { ( } \mathrm{Hz} \text { ) }\end{array}$ & $\begin{array}{c}\text { Daya Listrik } \\
\text { (kW) }\end{array}$ \\
\hline 1 & C 18 & \multirow{4}{*}{50} & \multirow{4}{*}{24,7927} & 47,4834 & 21,2343 \\
\hline 2 & 3408 & & & 40,2984 & 12,9801 \\
\hline 3 & 3406 & & & 30,7048 & 5,7416 \\
\hline 4 & 3306 & & & 22,3447 & 2,2128 \\
\hline
\end{tabular}

\subsection{Simulasi Penggunaan VSD Sebagai Pengatur Kecepatan Exhaust fan.}

Penggunaan VSD sebagai pengatur kecepatan exhaust fan disimulasikan menggunakan software simulink matlab berdasarkan data nilai exhaust gas flow rate empat diesel engine sesuai Tabel 2.3. Blok-blok yang dipakai pada simulink seperti Gambar 3.5 di bawah.

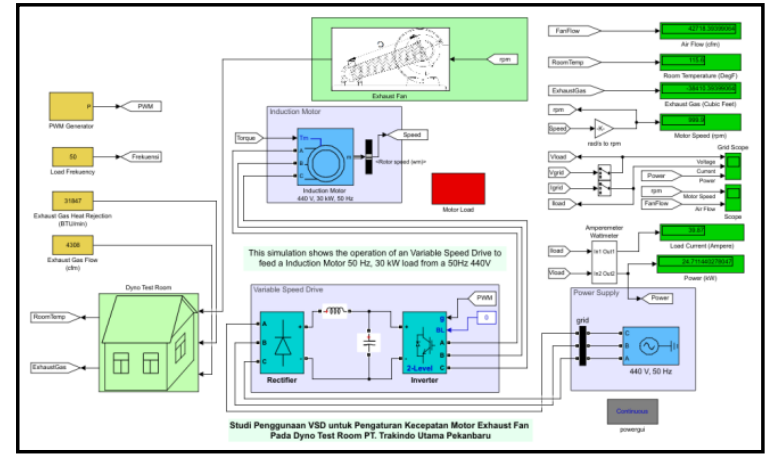

Gambar 3.5 Blok-blok yang dipakai pada simulasi simulink matlab.

Pengaturan blok-blok pada simulink didasarkan pada data lapangan yang diperoleh dan dari persamaan semua perhitungan yang diambil dari beberapa rujukan. Blok power supply diatur dengan nilai voltage phase to phase rms sebesar $440 \mathrm{~V}$ dengan frekuensi $50 \mathrm{~Hz}$ seperti Gambar 3.6 di bawah.

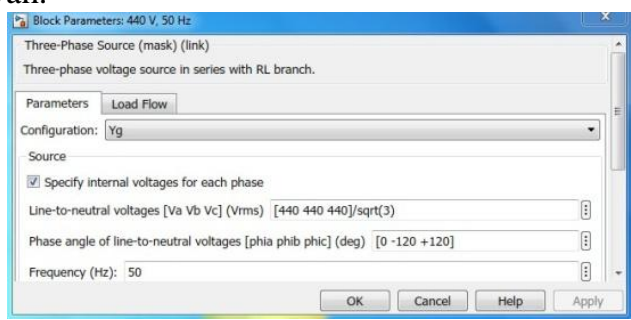

Gambar 3.6 Pengaturan Blok three phase source sebagai power supply utama.

Sedangkan blok VSD berdasarkan nilai default yang ada, saat simulasi nilai frekuensi dari $P W M$ generator sebagai pengendali utama VSD yang dapat diubah sesuai frekuensi yng diinginkan. Blok VSD terdiri dari rectifier dan inverter, pengaturannya seperti Gambar 3.7.

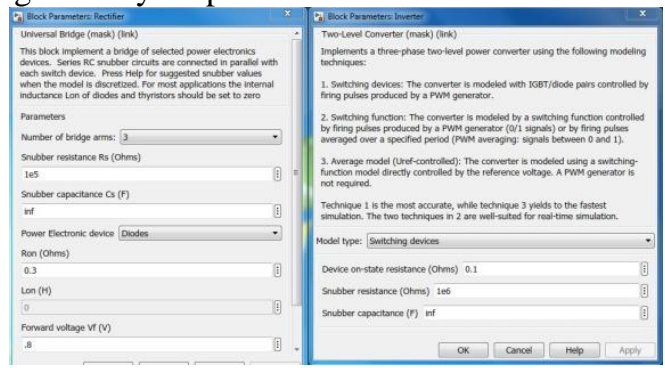

Gambar 3.7 Pengaturan Blok rectifier dan inverter sebagai satu kesatuan perangkat VSD..

Blok selanjutnya yang digunakan pada simulasi simulink adalah blok motor induksi tiga phasa. Blok motor induksi atau asynchronous machine diatur berdasarkan data motor induksi aktual yang tertera pada name plate motor yaitu 440 V $50 \mathrm{~Hz}$ dengan hasil pengukuran kecepatan 998 rpm dan arus listrik 40 A. Pengaturan blok motor induksi ini seperti Gambar 3.8. 


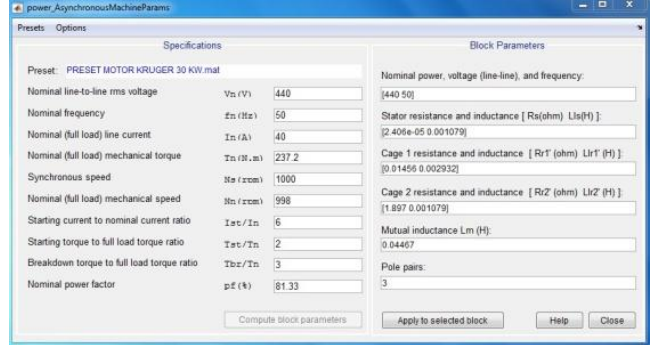

Gambar 3.8 Pengaturan Blok motor induksi.

3.2.1 Simulasi Pengoperasian Exhaust fan saat Load Test Engine model C18.

Simulasi simulink ini menggunakan data engine dengan model C18 caterpillar seperti data Tabel 2.3.
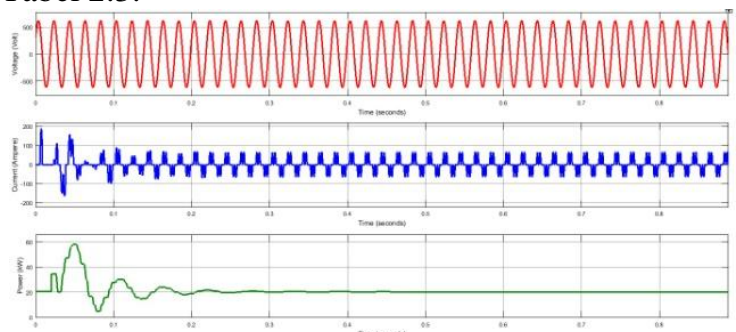

Gambar 3.9 Hasil simulasi nilai tegangan, arus dan daya listrik motor exhaust fan dengan beban gas buang engine $\mathrm{C} 18$.

Variable komponen input yang diatur diantaranya nilai exhaust flow rate diatur dengan nilai $4.308 \mathrm{cfm}$, heat rejection $31.847 \mathrm{btu} / \mathrm{min}$ dan nilai frekuensi 47,4834 Hz. Hasil simulasi ditunjukkan seperti Gambar 4.9. Dari hasil simulasi didapatkan nilai arus listrik rms 32,39 A dan tegangan rms phasa ke phasa $440 \mathrm{~V}$ sehingga konsumsi daya listrik didapatkan senilai 20,24 kW. Grafik dari blok scope memperlihatkan nilai yang relatif stabil dimulai pada detik ke 0,2 . Sedangkan visual grafik kecepatan motor ditunjukkan seperti Gambar 3.10.

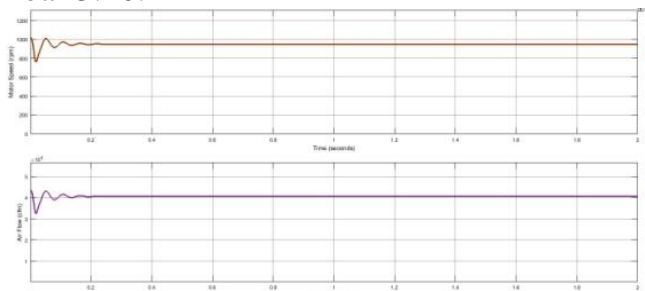

Gambar 3.10 Hasil simulasi nilai kecepatan dan air flow motor exhaust fan dengan beban gas buang engine C18.

Pada grafik Gambar 3.10 ditunjukkan nilai kecepatan motor senilai $950 \mathrm{rpm}$ yang sebanding dengan nilai air flow $40.600 \mathrm{cfm}$ pada saluran exhaust fan. Dari hasil simulasi ini didapatkan nilai kecepatan dan air flow yang cukup stabil dan dapat disimpulkan motor exhaust fan beroperasi normal. 3.2.2 Simulasi Pengoperasian Exhaust fan saat Load Test Engine model 3408.

Simulasi simulink ini menggunakan data engine dengan model 3408 caterpillar seperti data
Tabel 2.3. Variable komponen input yang diatur diantaranya nilai exhaust flow rate diatur dengan nilai $3.686 \mathrm{cfm}$, heat rejection $26.956 \mathrm{btu} / \mathrm{min}$ dan nilai frekuensi 40,2984 Hz. Hasil simulasi ditunjukkan seperti Gambar 3.11.

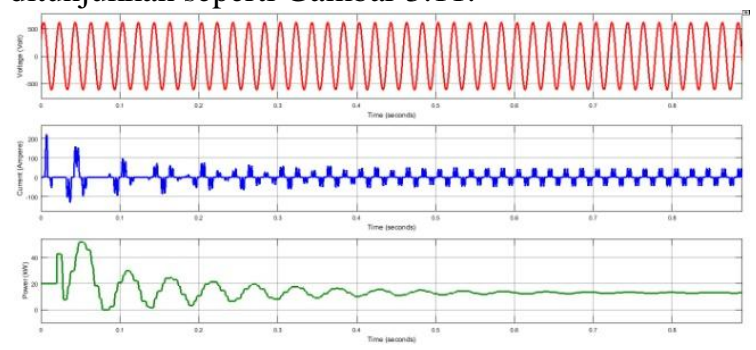

Gambar 3.11 Hasil simulasi nilai tegangan, arus dan daya listrik motor exhaust fan dengan beban gas buang engine 3408.

Dari hasil simulasi didapatkan nilai arus listrik $r m s$ 27,45 A dan tegangan $r m s$ phasa ke phasa $439 \mathrm{~V}$ sehingga konsumsi daya listrik didapatkan senilai 16,63 kW. Grafik dari blok scope memperlihatkan nilai yang relatif stabil dimulai pada detik ke 0,5. Sedangkan visual grafik kecepatan motor ditunjukkan seperti Gambar 3.12.

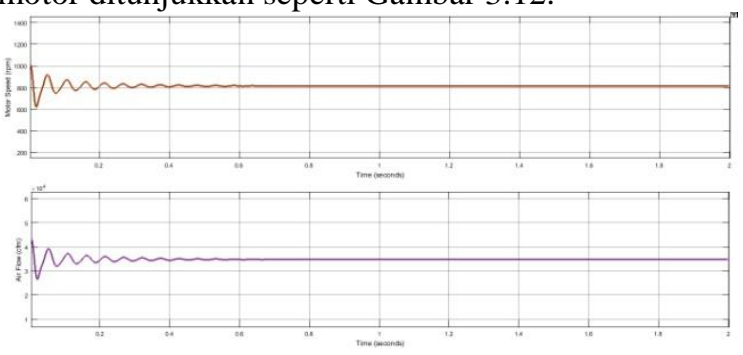

Gambar 3.12 Hasil simulasi nilai kecepatan dan air flow motor exhaust fan dengan beban gas buang engine 3408.

Pada grafik Gambar 3.12 ditunjukkan nilai kecepatan motor senilai $815 \mathrm{rpm}$ yang sebanding dengan nilai air flow 34.830 cfm pada saluran exhaust fan. Dari hasil simulasi ini didapatkan nilai kecepatan dan air flow yang cukup stabil dan dapat disimpulkan motor exhaust fan masih beroperasi normal.

3.2.3 Simulasi Pengoperasian Exhaust fan saat Load Test Engine model 3406.

Simulasi simulink ini menggunakan data engine dengan model 3406 caterpillar seperti data Tabel 2.3. Variable komponen input yang diatur diantaranya nilai exhaust flow rate diatur dengan nilai $3.015 \mathrm{cfm}$, heat rejection $20.302 \mathrm{btu} / \mathrm{min}$ dan nilai frekuensi $30,7048 \mathrm{~Hz}$. Hasil simulasi ditunjukkan seperti Gambar 3.13. 

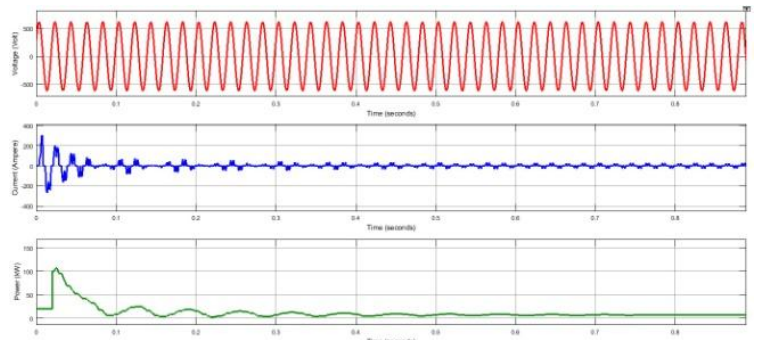

Gambar 3.13 Hasil simulasi nilai tegangan, arus dan daya listrik motor exhaust fan dengan beban gas buang engine 3406.

Dari hasil simulasi didapatkan nilai arus listrik $r m s$ 12,12 A dan tegangan $r m s$ phasa ke phasa $441 \mathrm{~V}$ sehingga konsumsi daya listrik didapatkan senilai 6,962 kW. Sedangkan visual grafik kecepatan motor ditunjukkan seperti Gambar 3.14.

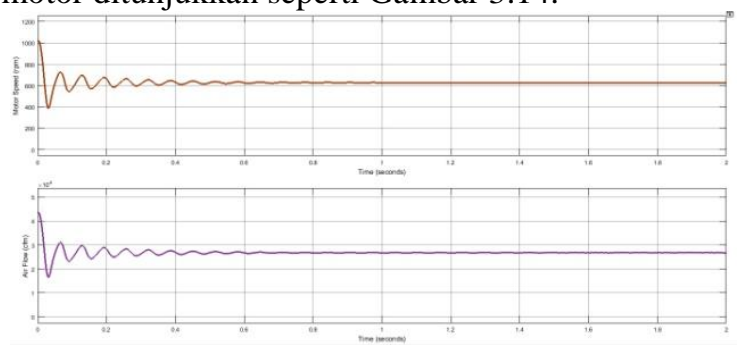

Gambar 3.14 Hasil simulasi nilai kecepatan dan air flow motor exhaust fan dengan beban gas buang engine 3406.

Pada grafik Gambar 3.14 ditunjukkan nilai kecepatan motor senilai $627 \mathrm{rpm}$ yang sebanding dengan nilai air flow 26.810 cfm pada saluran exhaust fan. Dari hasil simulasi ini didapatkan nilai kecepatan dan air flow yang juga stabil dan dapat disimpulkan motor exhaust fan beroperasi normal.

3.2.4 Simulasi Pengoperasian Exhaust fan saat

Load Test Engine model 3306.

Simulasi simulink ini menggunakan data engine dengan model 3306 caterpillar seperti data Tabel 2.3. Variable komponen input yang diatur diantaranya nilai exhaust flow rate diatur dengan nilai $2.055 \mathrm{cfm}$, heat rejection $14.956 \mathrm{btu} / \mathrm{min}$ dan nilai frekuensi 22,3447 Hz. Hasil simulasi ditunjukkan seperti Gambar 3.15.

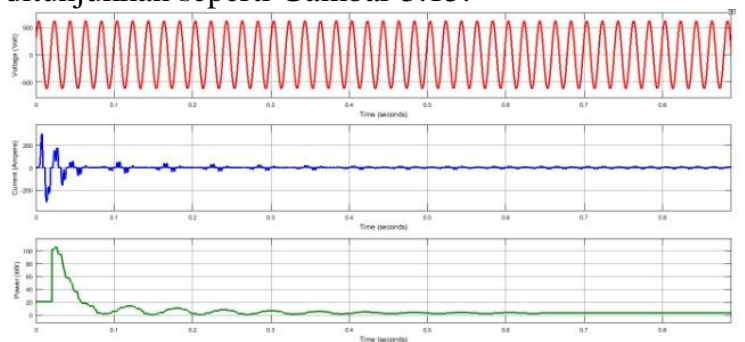

Gambar 3.15 Hasil simulasi nilai tegangan, arus dan daya listrik motor exhaust fan dengan beban gas buang engine 3306.

Dari hasil simulasi didapatkan nilai arus listrik rms senilai 4,918 A dan tegangan rms phasa ke phasa $439 \mathrm{~V}$ sehingga konsumsi daya listrik didapatkan cukup tinggi senilai $3,073 \mathrm{~kW}$. Grafik dari blok scope memperlihatkan nilai yang cukup stabil. Sedangkan visual grafik kecepatan motor ditunjukkan seperti Gambar 3.16.

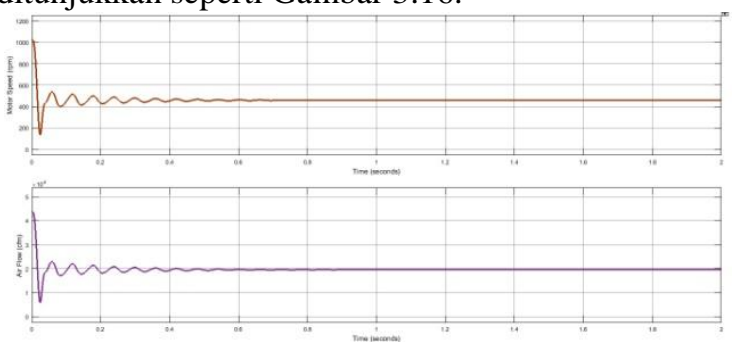

Gambar 3.16 Hasil simulasi nilai kecepatan dan air flow motor exhaust fan dengan beban gas buang engine 3306.

Pada grafik Gambar 3.16 ditunjukkan nilai kecepatan motor senilai $457 \mathrm{rpm}$ yang sebanding dengan nilai air flow $19.540 \mathrm{cfm}$ pada saluran exhaust fan. Dari hasil simulasi ini didapatkan nilai kecepatan dan air flow yang juga stabil dan operasional motor exhaust fan terlihat normal.

\subsubsection{Perbandingan Antara Hasil Perhitungan}

Dengan Simulasi.

Nilai-nilai yang didapatkan dari hasil perhitungan dan simulasi jika dilakukan highlight dalam satu waktu menunjukkan nilai yang relatif sama, perbedaan hasil simulasi simulink untuk pengaturan VSD dengan beberapa nilai frekuensi ini terletak pada waktu untuk mencapai nilai kecepatan motor yang stabil. Lebih jelasnya perbandingan nilai perhitungan dan simulasi seperti Tabel 3.7.

Tabel 3.7 Perbandingan Hasil Perhitungan dan Simulasi.

\begin{tabular}{|c|c|c|c|c|c|c|}
\hline \multirow[b]{2}{*}{ No } & \multirow[b]{2}{*}{$\begin{array}{l}\text { Model } \\
\text { Engine }\end{array}$} & \multirow[b]{2}{*}{$\begin{array}{c}\text { Frekuensi } \\
\text { (Hz) }\end{array}$} & \multicolumn{2}{|c|}{ Hasil Perhitungan } & \multicolumn{2}{|c|}{ Hasil Simulasi } \\
\hline & & & $\begin{array}{c}\text { Kecepatan } \\
\text { Motor } \\
\text { (rpm) }\end{array}$ & $\begin{array}{c}\text { Daya } \\
\text { Listrik } \\
(\mathrm{kW})\end{array}$ & $\begin{array}{c}\text { Kecepstan } \\
\text { Motor } \\
\text { (rpm) }\end{array}$ & $\begin{array}{c}\text { Dasya } \\
\text { Listrik } \\
\text { (kW) }\end{array}$ \\
\hline 1 & C 18 & 47,4834 & 947,7677 & 21,2343 & 950 & 20,240 \\
\hline 2 & 3408 & 40,2984 & 804,3556 & 12,9801 & 815 & 16,630 \\
\hline 3 & 3406 & 30,7048 & 612,8671 & 5,7416 & 627 & 6,962 \\
\hline 4 & 3306 & 22,3447 & 446,0011 & 2,2128 & 457 & 3,073 \\
\hline
\end{tabular}

Nilai-nilai yang didapat dari hasil simulasi mempunyai nilai yang mendekati dari hasil perhitungan. Yang perlu ditekankan disini adalah daya listrik yang terukur pada simulasi sebanding dengan perubahan yang terjadi pada nilai frekuensi VSD, hal ini sesuai dengan perhitungan-perhitungan yang dilakukan. Pengoperasian exhaust fan dengan beban gas buang dengan berbagai model engine ini menunjukkan nilai cukup stabil dan operasi motor normal.

\section{KESIMPULAN DAN SARAN}

\subsection{Kesimpulan.}

Berdasarkan hasil perhitungan yang dilakukan dalam bab pembahasan maka dapat disimpulkan sebagai berikut : 
1. Perubahan frekuensi sebesar $11 \%$ akan mengakibatkan meningkatnya kecepatan mekanikal rotor senilai $11 \%$. Perubahan kecepatan mekanikal rotor sebesar $11 \%$ akan mengakibatkan meningkatnya aliran udara yang dihasilkan senilai $11 \%$. Dari perubahan ketiga parameter tersebut maka nilai konsumsi daya listrik juga berubah, perubahan frekuensi, kecepatan motor dan aliran udara fan $11 \%$ akan meningkatkan atau menurunkan kebutuhan daya listrik $23 \%$.

2. Jika memperhatikan proses pengetesan engine Cat 3306 daya mekanik $349 \mathrm{hp}$ dengan putaran exhaust fan konstan sebelum penggunaan VSD memerlukan daya 24,7927 kW dan dari hasil perhitungan setelah penggunaan VSD jika disesuaikan dengan nilai air flow rate Exhaust Gas engine 3306 tersebut, hanya memerlukan daya listrik 2,2128 $\mathrm{kW}$ saja, maka dari hasil ini didapatkan nilai penghematan cukup signifikan sekitar $90 \%$ konsumsi daya listrik bias dikurangi.

3. Untuk engine C 18 Caterpillar kapasitas 831 hp yang sebelumya juga membutuhkan operasional exhaust fan dengan daya 24,7927 $\mathrm{kW}$ nilai sama untuk semua model engine, setelah penggunaan VSD dapat dikurangi sebesar $14,35 \%$ menjadi $21,2343 \mathrm{~kW}$ saja.

4. Selain penghematan operasional exhaust fan juga harus memperhatikan nilai-nilai yang efektif dan efisien dengan artian penghematan daya listrik tidak mempengaruhi kinerja dari exhaust fan itu sendiri, sehingga sistem fan tersebut tetap mampu membuang panas dan karbondioksida secara optimal dan aman untuk karyawan.

\subsection{Saran.}

Berdasarkan hasil analisa yang dilakukan dalam bab pembahasan maka ada hal-hal yang masih perlu diperdalam mengenai analisa-analisa selanjutnya sebagai berikut :

1. Penggunaan VSD sebagai pengatur kecepatan memang dapat menghemat konsumsi daya listrik. Namun pemakaiannya tetap saja memperhatikan biaya pemasangan apakah sebanding dengan keuntungan operasional nantinya. Untuk mengatasi nilai yang cukup mahal jika membeli VSD merk terbaik, diharapkan inovasi-inovasi kedepan tetaplah harus ada, jika kita mampu membuat rangkaian pengatur kecepatan sendiri dengan komponen-komponen relatif murah namun tidak kalah kualitasnya mungkin inilah yang terbaik.

2. Perlu penelitian lanjutan dengan analisa berdasarkan rujukan-rujukan mengenai pengoperasian VSD berdasarkan pembacaan sensor

\section{DAFTAR PUSTAKA}

Anindita. Galih, Setiawan. Edi, Syahid. Achmad, 2016, Optimasi Energi Pada Motor Induksi 3 Fasa Dalam Memproduksi Kebutuhan Air (Studi Kasus di PDAM Karang Pilang Surabaya), ISSN 2548-1509, Seminar Nasional Maritim Sains dan Teknologi Terapan Volume 1, Politeknik Perkapalan Negeri, Surabaya.

Bodkhe. S B, Aware. M V, 2009, A Variable-Speed, Sensorless, Induction Motor Drive Using DC Link Measurements, ISSN 2158-2297, Deparment of Electrical Engineering, G H Raisoni College of Engineering, Visvesvarya National Insitute of Technology, Nagpur, India.

Callawa. Cindy, M. Bagheri. Hassan, D. Aswegan. James, 2013, ASRAE Handbook, W. Stephen Comstock, Atlanta.

Caterpillar, 2015, Application \& Installation Guide Engine Room Ventilation, Caterpillar All rights reserved.

Chapman. Stephen J, 2012, Electric Machinery Fundamentals Fifth Edition, Mc Graw Hill Higher Education, New York.

Dietzel. Fritz, 1980, Turbinen Pumpen Und Verdichter, Vogel-Verlag, Wurzburg.

Kirshen. Daniel S, Novotny. Donald W, Lipo. Thomas A, 1985, On-Line Efficiency Optimization of a Variable Frequency Induction Motor Drive, ISSN 1939-9367, IEEE Transactions On Industry Applications Vol IA-21 No 4.

Kumolo. Daru, Sugiyantoro. Bambang, Firmansyah. Eka, 2014, Pengaruh Inverter Sebagai Alat Pengendali Frekuensi Terhadap Unjuk Kerja Motor Induksi Tiga Fase Sangkar Tupai, ISSN EIS03058, Jurnal Penelitian Teknik Elektro dan Teknologi Informasi Volume 1 Nomor 2, Yogyakarta.

Latt. Aung Zaw, Win. Ni Ni, 2009, Variable Speed Drive of Single Phase Induction Motor Using Frequency Control Method, ISSN 21551812, International Conference on Education Technology and Computer, Myitkyina. 
Prasetyadi, 2006, Modifikasi Putaran Fan Untuk Meningkatkan Efisiensi Pemakaian Listrik, ISSN 1441-318X, Jurnal Teknik Lingkungan Edisi Khusus Hal 9-16, Badan Pengkajian dan Penerapan Teknologi, Jakarta.

Rashid. Muhammad H, 2011, Power Electronics Handbook, Butterworth-Heinemann is an imprint of Elsevier, Burlington.

Rijono.Yon, 2004, Dasar Teknik Tenaga Listrik edisi revisi, Andi, Yogyakarta.

Sanda, 2012, Disain Blower Dan Cerobong Untuk Membuang Limbah Bau Dan Ozon Iradiator Gamma 500 kCi, ISSN 1410-9565, Jurnal Teknologi Pengelolaan Limbah Volume 15 Nomor 1, Pusat Rekayasa Perangkat NuklirBatan, Tangerang.

Theraja. BL, 1980, A Textbook Of Electrical Technology, Publication Division Of Nirja Contruction and Development, New Delhi.

Wang. Shan K, 2001, Handbook Of Air Conditioning And Refrigerantion, Mc Graw Hill, New York.

Wessel. Dennis J, Reeves. George, Claridge. David E, 2000, ASRAE Handbook, W. Stephen Comstock, Atlanta.

Zuhal, 2016, Dasar Teknik Tenaga Listrik Dan Elektronika Daya, PT Gramedia, Jakarta. 